Revised Version

July 28, 2014

Comments Solicited

\title{
Coauthors and Collaborations
}

by

\author{
Ronald G. Ehrenberg*
}

\begin{abstract}
$\underline{\text { Abstract }}$
This personal reflective essay summarizes and explains why the frequency with which I have coauthored research has varied over my career and discusses the reasons that my coauthored publications and collaborations have arisen. The reasons include research that arises from casual conversations with colleagues, the sharing of data both as a donor and as a recipient, invitations to participate in large scale projects, the division of labor and working with people with complementary skills and personalities, educating graduate and undergraduate students and the desire to give the former a leg up in the job market and to encourage the latter to pursue doctoral study, discussions with my wife about issues she faced as a teacher and administrator in public K12 education, and efforts to magnify my impact on an area of study by convening conferences, commissioning papers, and seeing conference volumes through to publication.
\end{abstract}

*Irving M. Ives Professor of Industrial and Labor Relations and Economics, Stephen H, Weiss Presidential Fellow, and Director of the Cornell Higher Education Research Institute (CHERI) at Cornell University. CHERI is supported by the Andrew W. Mellon Foundation and I am grateful to the Foundation for its long-term support which has made many of my publications over the last 20 years possible and to Orley Ashenfelter and Dan Hamermesh for their comments on an earlier draft. I am also grateful to Ali Olesewski, a Cornell undergraduate and a future coauthor, for her assistance in helping me tabulate and analyze the data that I used in this paper. 


\section{Introduction and Patterns to Explain}

It is hard for me to believe that I am now in my $45^{\text {th }}$ year as a publishing economist and more recently a higher education scholar. It is even harder for me to believe, as I scan my vita, the number of things I have written and the number of different people with whom I have coauthored pieces.

Table 1 is a summary of my publishing career and my coauthors as of July 2014. My publication counts include articles in academic journals (including proceedings volumes and comments), chapters in books, articles in science, economics and higher education magazines and newspapers (Scientific American, Regulation, Academe, and Change are examples), and books that I authored or coauthored. In the first column, for my career to date (as of June 2014), and in subsequent columns, for each 5 year interval, I indicate the number of publications, the number and share of these that were coauthored and the number that were coauthored by faculty (including visiting faculty and postdocs) at my own institution, my graduate students and former graduate students, my undergraduate students, faculty at other institutions, my wife and one of my sons, and other individuals. ${ }^{1}$

Over $60 \%$ of my publications have been coauthored. But contrary to the pattern observed by Dan Hamermesh (2014) for a set of 79 prominent labor economists, my propensity to coauthor has not increased monotonically with age. During the first 5 years of my career all my publications were sole authored because while on the faculty at the University of Massachusetts I had few colleagues with similar interests and very few

\footnotetext{
${ }^{1}$ The publication count does not include working papers that have not yet been published; many of which were coauthored with graduate students. My vita, which includes these, is available at http://faculty.cit.cornell.edu/rge2
} 
graduate students. ${ }^{2}$ After I moved to Cornell in 1975, my access to colleagues with similar interests and to graduate students dramatically increased. As a result during the next 25 years over $74 \%$ of my publications were coauthored. However, after 1999, my share of coauthored publications fell to about $49 \%$.

Fifty six of the coauthored publications have at least one current or former graduate student as a coauthor, 13 have at least one undergraduate student as a coauthor, 28 have at least one faculty member at my own institution as a coauthor, and 16 have at least one faculty member at another institutions as a coauthor. I also have coauthored papers with administrators and staff at my own institution, with my wife and one of my sons, and with individuals at other institutions who are not faculty members, including colleagues at the Andrew W. Mellon Foundation.

The number of different individuals with whom I have worked is large. The 78 different coauthors of the 169 publications include 32 different graduate students, 11 different undergraduate students, 18 different faculty and administrative colleagues at Cornell, and 15 different individuals at other institutions. ${ }^{3}$

The pattern of where my publications appear has changed over time. Table 2 shows the shares of my publications, each period and in total, that were in articles in academic journals, chapters in books, books, and articles in science, economics and higher education magazines. As I was I returning to my faculty position after serving as a Cornell vice president from 1995 to 1998 , I received some advice from a former provost at another university, who told me that life after administration is great but the experience makes you a different person and you have to do different things. I decided that in

\footnotetext{
${ }^{2}$ However, several coauthored papers written with an undergraduate student and other UMass faculty were published in later years

${ }^{3}$ These individuals are listed in Appendix A
} 
addition to conducting econometric research on higher education issues I wanted to write more policy related pieces and publish them in places that where I could influence how people think about higher education. So during the past 20 years, I have written 26 articles that have appeared in more popular higher education outlets.

Does where a publication appears influence whether a coauthor was involved? A logit analysis reported in the first column of table 3 shows that when the probability that a publication has a coauthor is assumed to depend only on a time trend and the type of publication (publications in journals are the omitted category), my publications in magazines are less likely to have coauthors. However, once one controls in the second column for whether the publication includes econometric research or the development of a formal theoretical model, where the publication appeared ceases to matter. The only variable which proves to be a predictor of having a coauthor is if the publication involved an econometric study. So the decline in the share of my publications that were coauthored after 1999 reflect my authoring more policy related and thought pieces (regardless of where they were published) and fewer econometric studies.

Dan Hamermesh found in his sample that the number of coauthors on each coauthored publication trended upward over time. As table 4 indicates, this is true also in my personal case. I attribute the growth in the number of my coauthors per coauthored piece to the growing numbers of graduate research assistants to whom I had access, to my more recent involvement of undergraduate students in research, and to the increased ease of simultaneously collaborating with multiple people in different places that changes in technology, most recently the development of the internet, have facilitated. 


\section{The Why's and Who's of Coauthors}

During 1970-71, my first year at the University of Massachusetts, I was invited to give a seminar at Princeton and met Orley Ashenfelter, one of the true giants in the field of labor economics. While we discussed my paper prior to the seminar, Orley pointed out an error in it. The paper presented the first empirical estimates of the wage elasticities of demand for state and local government employees, with a view toward making policy statements about whether there were any market forces that might limit the ability of emerging public sector unions to win large wage increases for their members. Its underlying theoretical model was based upon a variant of the Stone-Geary utility function ${ }^{4}$ that allowed public decision makers' utility to be a function only of increments in public sector employment levels above multiples (less than one) of previous employment levels (to capture incremental budgeting). Orley quietly explained to me that if I really believed that a Stone-Geary utility function was the correct specification, there was nothing for me to estimate because this utility function implied that all the own wage elasticities of demand were minus one.

We then went into the seminar where Orley remained absolutely silent and allowed me to explain that the model was meant only to heuristically motivate the empirical research and that the empirical specifications should not be interpreted as being derived directly from the model. My paper was ultimately published in the American Economic Review. ${ }^{5}$ Using my data and a more flexible system of demand equations that could be explicitly derived from another form of utility function, Orley and I went on to

\footnotetext{
${ }^{4}$ Richard Stone (1954)

${ }^{5}$ Ronald Ehrenberg (1973)
} 
write my first coauthored paper and it was published in a volume edited by Dan Hamermesh. ${ }^{6}$ Orley also invited me to work with him as a consultant in Washington DC in 1972-73 where he was heading up the Office of Evaluation of the U.S Department of Labor. My experiences working with him in Washington led me to focus much of my early research on analyzing the effects of labor market legislation and policies.

Dan, who I first met in 1968 and who became a lifelong friend, was directly responsible for my second coauthored paper. Following in the tradition of Gary Becker's household allocation of time model and Michael Grossman's paper on the allocation of time and money to investments in health capital over the life cycle, Dan coauthored the first paper by an economist on the economics of suicide in $1974 .^{7}$ Being a relatively competitive person in my youth, even with friends, I wondered what I could do to "top" Dan's paper. While talking at a party to Corry Azzi, who was visiting the University of Massachusetts, we decided as a joke to work on a model in which individuals make decisions on allocating time each period to the labor market and to religious activities, with the goal of maximizing consumption during both their lifetimes and in the afterlife. ${ }^{8}$

What started out as a joke soon became a serious research effort, as we found there were a variety of empirical observations about participation in religious activities that psychologists and sociologists had made, with different explanations provided for each observed regularity. Shortly thereafter we had developed a lifecycle household allocation of time model that could explain all of these observations plus others and then empirically tested the model. Our resulting paper, which is still one of my most highly

\footnotetext{
${ }^{6}$ Orley Ashenfelter and Ronald Ehrenberg (1975)

${ }^{7}$ Michael Grossman (1972), Daniel Hamermesh and Neal Soss (1974)

${ }^{8}$ Recently Dan told me that his suicide paper also started as a joke.
} 
cited works, led ultimately to the development of a new now thriving subfield that addresses the economics of religion. ${ }^{9}$

Other coauthored work quickly followed as a result of my relationship with Orley. While in DC, I learned about Ron Oaxaca, a recent Princeton PhD student of Orley and Al Rees, who was teaching at a Canadian university. We quickly hired Ron at the University of Massachusetts and together he and I wrote the first theoretical and empirical paper that applied my dissertation advisor Dale Mortensen's theory of job search to estimate the impact of unemployment insurance benefits on unemployed workers durations of unemployment and post unemployment earnings. ${ }^{10} \mathrm{We}$ both soon left the university, Ron going to the University of Arizona and me to Cornell, and sadly we never worked on other issues together.

I also met Bob Smith, a Stanford $\mathrm{PhD}$, who was on leave from the University of Connecticut, and also working with Orley. Orley and Al had been appointed a two-person visiting committee to advise the Dean of the ILR School at Cornell on how to move its then institutional labor economics group towards the new breed of empirical micro labor economists. They recommended a list of people to hire and after Dan, who was first on the list, turned Cornell down, the next two offers were made to Bob Smith and me. Although Dan and I have only coauthored one short piece during our careers, his impact on my career by his not accepting the Cornell offer was extraordinary. ${ }^{11}$

Bob and I have now been Cornell colleagues for almost 40 years. While we coauthored 5 empirical papers together early in our careers, our most enduring collaboration was the writing of our textbook Modern Labor Economics whose first

\footnotetext{
${ }^{9}$ Corry Azzi and Ronald Ehrenberg (1975)

${ }^{10}$ Ronald Ehrenberg and Ronald Oaxaca (1976)

${ }^{11}$ Ronald Ehrenberg, Daniel Hamermesh, and George Johnson (1977)
} 
edition appeared in $1982 .{ }^{12}$ Our students at Cornell back then were not very interested in formal mathematics and so our goal was to write a text that explained theories heuristically (without lots of math) and then concentrated on applying the theories to illustrate the usefulness of labor market models in understanding proposed policy changes and the evolution of labor market institutions.

Writing a textbook in any field is a daunting challenge because one's interests may only be in subsections of the field. Our collaboration was facilitated by our different interests. For example, I wrote the first draft of our chapters on labor demand and Bob wrote the first draft of chapters on labor supply. I wrote about the economics of collective bargaining in the private and public sectors and Bob wrote about compensating wage differentials and contract models. But more than differences in our topical interests, our collaboration was facilitated by the differences in our personalities. Throughout my career I have had days of extreme productivity and other days in which I sit around my office and accomplish nothing. Bob is a very steady person and by working together he "evened" out my fluctuations in productivity. So differences in personality types may also facilitate collaboration.

Our textbook is now in its $12^{\text {th }}$ edition and it remains the leader in the field. But the last edition that I had anything to do with was published in the mid-1990s. From 1995 to 1998 I served as a Cornell's Vice President for Academic Programs, Planning and Budgeting and when I returned to the faculty my interests were focused much more narrowly on the economics of higher education. Since then Bob has revised the book every three years on his own and kept my name on it for "branding" purposes. Modern

\footnotetext{
${ }^{12}$ Ronald Ehrenberg and Robert Smith (1982)
} 
Labor Economics is by far "my" most highly cited work and it is only fair that I publicly thank Bob for the impact his revisions have had on my reputation.

During the first 12 years of my career I worked hard at staying at the frontiers of econometrics and tried to use a new (to me) econometric technique in each paper that I wrote. But I had a revelation (unrelated to my work on the economics of religion) when I attended a week long course on longitudinal data models taught at NORC at the University of Chicago during the summer of 1982. As I sat through the lecture presented by distinguished scholars, including economist Gary Chamberlain (then at Wisconsin), I realized that I did not have the time or energy to both focus on economic issues that interested me and to stay at the frontiers of econometrics methods. Gary had brought a $\mathrm{PhD}$ student from Wisconsin named George Jakubson with him to serve as the teaching assistant in the class and I realized it made sense for us to try to hire at Cornell younger colleagues who had skills such as George had to help train our PhD students and to work with me on empirical projects.

The next year we actually hired George and he is the Cornell colleague with whom I have coauthored the largest number of research publications. These have included a book on the impact of advance notice provisions for layoffs in union contracts on displaced workers labor market outcomes (which was cited in the debate that led to the enactment of the WARN legislation), a paper on who bears the cost of university expenditures out of institutional funds on research, two papers on $\mathrm{PhD}$ students' times to degree and completion probabilities, and a paper on whether the gender mix of academic 
leaders influences the rate at which academic institutions diversify their faculty across gender lines. ${ }^{13}$

During the late 1980s, William Bowen, then President of the Andrew W. Mellon Foundation began the Foundation's support for the economics of education by making a grant to the National Bureau of Economic Research to for a volume on the economic challenges facing higher education. Charles Clotfelter from Duke was asked by the NBER to head up the project and Charlie, who had read some of my early papers on higher education but had never met me, invited me to join him on the project. Together with Malcolm Getz and John Siegfried from Vanderbilt, we produced what became my first coauthored book on the economics of higher education. ${ }^{14}$ While Charlie and I never coauthored another piece, he went on to direct, and I to participate in, a working group on the economics of higher education that met regularly at the NBER for almost 20 years. Many members of this group were current or former higher education administrators including Charlie and Gordon Winston from Williams; both Charlie and Gordon became very close friends of mine. My discussions with members of the group, helped to shape much of my subsequent research agenda, even though these discussions only occasionally led to coauthored work.

The financial support that I have received for the Cornell Higher Education Research Institute (CHERI) from the Andrew W. Mellon Foundation was for many years unrestricted; this allowed me to address whatever research issues I felt were important. However, around 2002 Bowen called me and told me that the Foundation was in the process of evaluating a major 10-year program of theirs to improve doctoral education in

${ }^{13}$ The book was Ronald Ehrenberg and George Jakubson(1988)

${ }^{14}$ Charles Clotfelter, Ronald Ehrenberg, Malcolm Getz and John Siegfried (1992) 
the humanities called the Graduate Education Initiative., which had cost the Foundation over $\$ 85$ million dollars

They had been collecting administrative data for about 100 treatment and comparison departments involved in the program for ten years before the program began and for each year of the program's duration on students' characteristics and their annual sources of support and progress towards their degree. The Foundation now was going to collect retrospective data on students' views of their doctoral program characteristics and their early career outcomes after they left or completed their programs. Bowen asked if I would be interested in helping to design the retrospective survey and then to conduct an evaluation of what the impact of the program had been on times to degree and completion rates and on what had been learned about the characteristic of doctoral program that facilitated student success if they provided me with supplementary funds for several years for a postdoctoral fellow?

I jumped at the opportunity and embarked on 8-year collaboration with Harriet Zuckerman, a very distinguished sociologist who was the senior Vice President of the Foundation, Sharon Brucker, the researcher at the Foundation who was in charge of the data bases, and Jeff Groen, a new University of Michigan $\mathrm{PhD}$ economics who assumed the postdoc position with me. Many preliminary publications and econometric papers later, we published our final book summarizing what we had learned in $2010 .{ }^{15}$ Sometimes co authorship arises because you get the rare opportunity to participate in a major data collection effort and evaluate an important program.

One of the true pleasures of my life has been my interactions with PhD students in economics and education, many of whom have become lifelong friends. To date I have

${ }^{15}$ Ronald Ehrenberg, Harriet Zuckerman, Jeffrey Groen and Sharon Brucker (2010) 
chaired the dissertation committees of 45 completed $\mathrm{PhDs}$ and served on the committees of numerous other PhD students. I have worked with these students on research to enhance their graduate education, to hopefully give them a leg up in the job market by coauthoring with them, and to increase my own research productivity. During the early years I taught them econometric research methods, now I depend upon many younger colleagues at Cornell, including George, to do this for me.

For the first 25 years of my career I had a self-imposed rule that I would not coauthor with any graduate student after he or she had received a $\mathrm{PhD}$. In retrospect, my publication record might have been much longer if I had continued to take advantage of all the human capital that I had helped to create. But, I felt that it was important for former students to create their own research programs and to make clear to the world that they were separated from their former advisors and "flying" on their own.

The rule was bent while I was a Cornell vice president. I had previously written a paper with Dominic Brewer while he was a PhD student on the early career labor market returns to attending a selective private academic institution. ${ }^{16}$ That paper was based on longitudinal data from students graduating from high school in the 1970s. Dominic and Eric Eide, a colleague he had met after receiving his degree, decided to extend the analysis to include a later cohort of students to see if the earnings advantage to going to a selective institution had persisted or grown over time and, in a second paper, to see if attendance at a selective private institution also enhanced the probability that college graduates enroll in graduate and professional degree programs.

\footnotetext{
${ }^{16}$ Ronald Ehrenberg and Dominic Brewer (1996)
} 
Knowing that I was busy administering, Dom invited me to be a coauthor with the understanding that my role would only be to comment on drafts that Eric and he wrote. ${ }^{17}$ Put simply Dom wanted to help me maintain my research productivity during my administrative hiatus. Since that time I have occasionally broke my rule coauthoring two additional papers with him, and two papers with three other former PhD students. Dom, who is now the Dean of the Steinhardt School of Culture, Education and Human Development at New York University, is the individual with whom I have coauthored the largest number of papers (10) during my career.

The two later papers that I wrote with Dom came about when I was invited by a Cornell colleague psychologist Steve Ceci to chair a team of scholars with diverse disciplinary backgrounds to write a review paper for a psychology journal surveying what we know about the impact of class size on student performance. An incentive to do this was the commitment that a popular version of the paper would be published in Scientific American, which has a monthly circulation over 450,000.

Realizing that more people would read that version than the sum of everything else that I had written during my career, I immediately agreed and suggested that Dom, who then was then a vice president and Director of Education Research at the Rand Corporation, be added to the team. He was added and the committee of editors choosing the team also selected a sociologist, Adam Gamoran from the University of Wisconsin, and a Canadian statistician, J. Douglas Willms. I had never previously met either Adam or Doug. Over about a year, via email and conference calls, we developed an outline for the papers, took turns writing sections, and then revised and finished the work. ${ }^{18}$ While

\footnotetext{
${ }^{17}$ Eric Eide, Dominic Brewer and Ronald Ehrenberg (1998) and Brewer, Eide, and Ehrenberg (1999)
}

${ }^{18}$ Ronald Ehrenberg, Dominic Brewer, Adam Gamoran and J. Douglas Willms (2001a) (2001b) 
subsequently I met, and served on a National Research Council committee with Adam, to this day I still have not met Doug. Sometimes coauthors can be strangers.

In actuality, while I was a Cornell vice president I was able to continue my research because I supervised the office of institutional research and I figured out ways to conduct research that was both relevant for decision making at Cornell and had academic value. I wrote papers with colleagues in the office on how Cornell was responding to the elimination of mandatory retirement for tenured faculty and on the 1990s National Research Council ratings of $\mathrm{PhD}$ programs. ${ }^{19}$ Earlier in my career, having served on many faculty committees relating to the economics of higher education and developing close relations with many university administrators, I also wrote a paper with Cornell's Dean of Admissions and Financial Aid on the "death" of need based financial aid policies. ${ }^{20}$

Sometimes collaborations arise because of who has the data. I met James Monks, now a faculty member at the University of Richmond but then a researcher at the Consortium of Financing Higher Education (COFHE), at a NBER Higher Education Working group meeting in the mid-90s. We began to talk about whether the USNWR rankings of colleges might influence institutions' admissions outcomes. COFHE is a consortium of over 30 selective private colleges and universities and Jim had access to confidential longitudinal data on admissions outcomes that COFHE collected. A collaboration quickly developed between us; he and I specified estimating equations, he did all the empirical analyses at COFHE preserving the confidentiality of the data, and

\footnotetext{
${ }^{19}$ Ronald Ehrenberg, Michael Matier and David Fontanella (2000), Ronald Ehrenberg and Peter Hurst (1996) (1998)

${ }^{20}$ Ronald Ehrenberg and Susan Murphy (1993)
} 
we wrote the first empirical paper on how the USNWR rankings influence admissions outcomes. $^{21}$

To take another example relating to who has the data, as a labor economist, I believe that in competitive labor markets compensating wage differentials exist for favorable and unfavorable job characteristics. If an academic institution offered its assistant professors a high probability of ultimately receiving tenure, which is a favorable job characteristic, it should, according to labor market theory be able to pay its assistant professors lower starting salaries than otherwise comparable institutions that offered lower probabilities of being granted tenure. But no one had ever empirically tested this proposition.

I knew that two former Northwestern economics $\mathrm{PhD}$ students of more recent vintage than me, Rachel Willis (University of North Carolina) and Paul Pieper (University of Illinois at Chicago) had collected data on the careers of all economists who had received $\mathrm{PhDs}$ in economics from U.S universities during the decade of the 1970s. With their data, I would be able to compute the probability that new PhDs who had taken first jobs as assistant professors at an economics department during the 1970s received tenure at the either that department or a department of equal or better quality. I invited them to work with me on a project. We coupled their data with data on starting salaries of new assistant professors at each doctoral level economics department during the 1970s, which the American Economic Association provided to us under conditions of strict confidentiality, and estimated equations that showed that compensating wage differentials for tenure probabilities exist in academia, at least for economics faculty. Other factors

\footnotetext{
${ }^{21}$ James Monks and Ronald Ehrenberg(1999)
} 
held constant, higher probabilities of receiving tenure were associated with lower starting salaries for assistant professor in economics. ${ }^{22}$

Sometimes my coauthors were family members. As the son of two NYC public school teachers and the husband of a woman whose career in public K12 education spanned teaching, school administrative, and district wide administrative positions, culminating in her serving for 9 years as a superintendent of a large high performing suburban school district in the Albany NY area, I have always been interested in K12 education and have a stream of publications on K12 topics.

Several issues that my wife Randy brought home from her work led directly to coauthored publications with her. When she was a middle school vice principal, her school district offered an early retirement incentive program, but did not allow teachers to "buy out" their unused sick leave days at retirement. She observed that an unusually large number of older teachers were frequently absent on Fridays and Mondays that year and she concerned about the impact of their absences on students.

Her concern led us, to collect district-level data for school districts in New York State and conduct an econometric study on how teacher absenteeism depends upon provisions in districts' collective bargaining agreements, on how teachers' absenteeism influences students' absenteeism, and on how teachers' and students' absenteeism influence students' test score performance. We were aided in our research by our older son Eric, then a high school senior, who helped me to code school district contracts, which were on file in Albany, for which he was added as a coauthor. Another coauthor,

\footnotetext{
${ }^{22}$ Ronald Ehrenberg, Paul Pieper and Rachel Willis (1998)
} 
who did most of the econometric work, was graduate student Dan Rees, son of Al Rees. ${ }^{23}$ Dan, I am proud to report, is now the editor of the Economics of Education Review.

Another time, back in the mid-1980s, when the debate over merit pay for teachers was just beginning, my wife wondered why there was no discussion of merit pay for school administrators. As a researcher who was aware of the literature on the incentive effects of compensation agreements for corporate CEOs, it immediately struck me that we could do a study to see if school superintendents in New York State were rewarded for performance. This study required us to econometrically define performance measures (such as keeping test scores higher than predicted and keeping expenditures per student lower than predicted given the characteristics of the district) and to see how such measures impacted upon school superintendents' compensation in their current positions and their mobility to higher paying and/or larger districts. Because we had longitudinal data, we were also able to observe, from knowledge of which superintendents were moving, whether knowing who the superintendent was in a district appeared to influence the school district's performance. Again our empirical research was conducted primarily by a $\mathrm{PhD}$ student, Richard Chaykowski, who is now a professor at Queens University in Canada. $^{24}$

Still a third joint project with my wife resulted from when she was being interviewed for her school superintendent position in the spring of 2001. Five school board members from the district came to Ithaca, where she was then the Deputy Superintendent of Schools, to interview practically everyone in the community and to

\footnotetext{
${ }^{23}$ Ronald Ehrenberg, Randy Ehrenberg, Daniel Rees and Eric Ehrenberg (1991). Eric went on to publish his own paper on K12 education while enrolled at Georgetown Law School (Eric Ehrenberg, 1996). My younger son Jason rejected the opportunity to coauthor with me on research while he was a high school student, but the publication bug bit him while he was at Michigan Law School (Jason Ehrenberg 1999)

${ }^{24}$ Ronald Ehrenberg, Richard Chakowski and Randy Ehrenberg (1988a) (1988b)
} 
also meet with me. At dinner that evening, one of the board members mentioned that the district had never lost a school budget vote; in New York State taxpayers vote on school budgets each spring. That immediately led us to wonder if there was a literature on school budget vote success and ultimately, my wife and I, along with Cornell undergraduate, Chris Smith and PhD student Liang Zhang wrote an empirical paper on the determinants of school budget vote success. ${ }^{25}$ As an experienced administrator, my wife understood division of labor and delegation; she and I developed the ideas and the students did the work. Other papers I wrote on K12 education issues arose from topics we had talked about but, due to constraints on her time, on which she chose not to work on with me. Without access to many graduate assistants at the University of Massachusetts, I began my first paper with an undergraduate coauthor while I was there. I was interested in whether local union building trade leaders called chief business agents were rewarded for their performance. They perform many functions but negotiating labor contracts is an important role. Data on the wages scales of different building trade unions (carpenters, painters, etc.) by city were published regularly and I wondered if these business agents' salaries were tied to how high their members' wage scales were as compared to the same trade's wage scales in other cities and the wage scales of other trades in the same city.

Data on the salaries of the chief business agents were available only in paper form at the Labor-Management Services Administration offices at the U.S Department of Labor in Washington DC. A bright undergraduate student was going down to DC for a semester on an internship and, with the promise of being a coauthor; he spent his lunch hours for several months copying this information for us. He and I worked on the

${ }^{25}$ Ronald Ehrenberg, Randy Ehrenberg, Christopher Smith and Liang Zhang (2004) 
econometric analyses when he returned. Our paper was published in 1977 after I arrived at Cornell; by then he was a graduate student at Northwestern. ${ }^{26}$

Over the next twenty years, flush with graduate research assistants, I produced many PhD students, but very few of our ILR undergraduate students went on for PhDs in economics. ${ }^{27}$ When I returned to the faculty after my stint as a Cornell vice president, I also decided that if I cared about the flow of future PhDs in economics and related fields it was important for me to involve undergraduate students in research early in their academic careers. I have described how I do this elsewhere, but partially it involves my being able to hire undergraduate students as research assistants through the funding for CHERI that I have received from the Andrew W. Mellon Foundation and other sources. ${ }^{28}$ Since 1998 I have employed almost 50 Cornell undergraduate students as research assistants and written 12 papers that have had at least one undergraduate coauthor, with 10 different undergraduate students being coauthors of these papers. My most frequent undergraduate coauthor is Chris Smith, who went on to receive a $\mathrm{PhD}$ in economics at MIT and is now an economist with the Federal Reserve Board of Governors in DC. Seven of my other undergraduate CHERI research assistants have either received $\mathrm{PhDs}$ in economics or public policy, or are currently enrolled in $\mathrm{PhD}$ programs in these fields.

The count of my coauthored papers with undergraduate students is smaller than it should be because I "gave away" one coauthored paper to the two undergraduate students working on it. I had obtained data from Cornell on the number of $\mathrm{PhD}$ students that each Cornell faculty member had supervised over a seven year period and planned to conduct

\footnotetext{
${ }^{26}$ Ronald Ehrenberg and Steven Goldberg (1977)

${ }^{27}$ But those that did became extraordinarily successful academics including David Bloom (Harvard), Alan Krueger (Princeton), Phil Levin (Wellesley), and Peter Capelli (Pennsylvania)

${ }^{28}$ Ronald Ehrenberg (2005)
} 
analyses of how and why the Gini coefficient for the inequality of faculty workloads in supervising $\mathrm{PhD}$ students varied across disciplines at Cornell and why faculty productivity in supervising $\mathrm{PhD}$ students within a discipline varied across individual faculty members.

The students working on the paper got so excited about doing the research that I realized, especially since the marginal value of an additional publication or citation was so low to me at that stage of my career, that they really did not need me to be a coauthor. They completed the project on their own, working on responding to referees' comments, even after they had graduated, that included implementing econometric methods with which I was unfamiliar. The paper was accepted for publication ${ }^{29}$ and while I can't list it on my vita, I am very proud of it. Based at least partially on that paper, one of the coauthors, Peter Crosta, was accepted, and went on to receive a $\mathrm{PhD}$ in the economics of education, at Columbia Teachers College.

\section{Collaboration Without Being a Coauthor}

About 20 years into my career, I realized that one's impact on an area of study can be magnified if one serves as a convener of a conference with a set of commissioned papers on an important topic, and then sees the conference through to publication. Over the years I have edited or coedited 11 conference volumes or journal symposia. Sometimes I have had a sole authored or coauthored paper within the volume, but the impact of each of these volumes has been much greater than the impact of my own paper.

Table 5 contains a listing of the 11 volumes and symposia, which are not included in the publication counts found in table 1 . Several had a coeditor who helped me to organize the underlying conference and edit the volume. These coeditors include a

\footnotetext{
${ }^{29}$ Peter Crosta and Iris Packman (2005)
} 
Cornell faculty colleague (Fran Blau), a faculty member at another university (Paula Stephan), a university President (F. King Alexander), the Director of the TIAA-CREF Institute (Madeleine d'Ambrosio) and a colleague from the National Research Council (Charlotte Kuh). Six of the last 7 resulted from conferences that I organized at the Cornell Higher Education Research Institute.

The last, the symposium on "Persistence Rates in STEM Field Majors", consisted of five papers; three of them were authored by $\mathrm{PhD}$ students of mine who were graduate research assistants at CHERI. I helped to design each of the studies and initially planned to be listed as the second coauthor of each of the papers. But as the students got into the research I realized that they did not need my help in finalizing the design of the studies and conducting the empirical research. I also made the judgment that a sole authored publication might mean more to them than being the first author of a joint publication with me. So, again given that the marginal value to me of additional publications and citations is now approaching zero, I removed my name from those papers and have another three fewer coauthored papers listed on my vita. Some colleagues have suggested to me that having a joint paper with a distinguished senior faculty member might be worth more to a PhD student in the job market than having a sole authored paper on their own, however all three of these $\mathrm{PhD}$ students wound up with jobs at universities.

\section{Concluding Remarks}

As this essay has shown, my coauthors and collaborations have arisen for many reasons. To enumerate just a few, these include conversations with faculty colleagues and colleague elsewhere about research by others or policy issues; sharing of data both as a donor and as a recipient; invitations to participate in larger projects; the division of labor 
and working with people who have complementary skills and personalities; educating graduate and undergraduate students and the desire to give the former a leg up in the job market to encourage the latter to consider $\mathrm{PhD}$ study; discussions with my wife about issues she faced as a teacher and an administrator in public education; and efforts to magnify my impact on an area of study by convening conferences, commissioning papers, and seeing them through to publication.

Writing reflective essays is a labor of love. I have written a number of previous reflective pieces and have found that they help me to understand what I have done, why I have done these things, where I am today, and what I want to do in the future. I regularly encourage my faculty colleagues and my graduate students, to think about doing similar pieces during their careers. ${ }^{30}$

Writing this piece was a special pleasure because it provided me the opportunity to think back on all of the coauthors I have worked with who have had such important impacts on my career and life. Many of these coauthors - colleagues from Cornell and around the country, and former graduate and undergraduate students - have become lifelong friends. So add to the reasons that I have enumerated in this paper for being a coauthor what is perhaps the most important one; the friends you make.

\footnotetext{
${ }^{30}$ Ronald G. Ehrenberg (1999) (2005) (2009)
} 


\section{References}

Orley Ashenfelter and Ronald Ehrenberg, "The Demand for Labor in the Public Sector" in Daniel Hamermesh ed. Labor in the Public and Non-profit Sectors (Princeton NJ: Princeton University Press, 1975)

Corry Azz1 and Ronald Ehrenberg, "Household Allocation of Time and Church Attendance”, Journal of Political Economy_83(February 1975):27-56

Dominic Brewer, Eric Eide, and Ronald Ehrenberg, "Does it Pay to Attend an Elite Private College: Cross-Cohort Evidence on the Effects of College Type on Earnings", Journal of Human Resources_34(Winter 1999): 104-123

Charles Clotfelter, Ronald Ehrenberg, Malcolm Getz, and John Siegfried, Economic Challenges in Higher Education (Chicago IL: Univ. of Chicago Press, 1991)

Peter Crosta and Iris Packman, "Faculty Productivity in Supervising Doctoral Students at Cornell University", Economics of Education Review 24(February 2005):5565

Eric Ehrenberg, "Getting to School: A Proposal for a Federal School Choice Transportation Tax Credit", Journal of Law and Education 25 (Spring 1996):199-218

Jason Ehrenberg, "A Call for Reform of Recent Immigration Legislation”, Michigan Journal of Law Reform 32 (Fall 1998)

Ronald Ehrenberg, "The Demand for State and Local Government Employees", American Economic Review 63(June 1973):366-379

Ronald Ehrenberg, "My Life and Economics", American Economist 43(Spring 1999):9-18

Ronald Ehrenberg, "Involving Undergraduates in Research to Encourage Them to Undertake PhD Study in Economics", American Economic Association Papers and Proceedings 95(May 2005):194-198

Ronald Ehrenberg, "Being a Quadruple Threat Keep Things Interesting" in Gretchen Bataille and Betsy Brown eds. Faculty and Career Paths (Lanham MD: Rowman \& Littlefield, 2006)

Ronald Ehrenberg, "Last Lecture" (June 2009) (available at http://faculty.cit.cornell.edu/rge2 )

Ronald Ehrenberg and Dominic Brewer, "Does it Pay to Attend an Elite Private College", Research in Labor Economics 15 (1996) 
Ronald Ehrenberg, Dominic Brewer, Adam Gamoran, and J. Douglas Willms, "Class Size and Student Achievement", Psychological Science in the Public Interest 2 (May 2001): 1-30 (2001a)

Ronald Ehrenberg, Dominic Brewer, Adam Gamoran, and J. Douglas Willms, “Does Class Size Matter”, Scientific American 285 (November 2001):78-85

Ronald Ehrenberg, Richard Chaykowski, and Randy Ehrenberg, "Determinants of the Compensation and Mobility of School Superintendents", Industrial and Labor Relations Review 41 (April 1988):386-401 (1988a)

Ronald Ehrenberg, Richard Chaykowski, and Randy Ehrenberg, "Are School Superintendents Rewarded for Performance" in David Monk and Julie Underwood eds. Micro Level School Finance: Issues and Implications for Policy ( American Education Finance Association, 1988) (1988b)

Ronald Ehrenberg, Randy Ehrenberg, Daniel Rees, and Eric Ehrenberg, "School District Leave Policy, Teacher Absenteeism, and Student Achievement", Journal of Human Resources 26(Winter 1991):72-105

Ronald Ehrenberg, Randy Ehrenberg, Christopher Smith and Liang Zhang, "Why Do Budget Referenda Fail?" Educational Evaluation and Policy Analysis 26 (Spring 2004):111-125

Ronald Ehrenberg and Steven Goldberg, "Officer Performance and Compensation in Local Building Trades Unions", Industrial and Labor Relations Review 30(January 1977):188-196

Ronald Ehrenberg, Daniel Hamermesh and George Johnson, "Policy Decisions and Research in Economics and Industrial Relations: An Exchange of Views", Industrial and Labor Relations Review 31 (October 1977): 10-13

Ronald Ehrenberg and Peter Hurst, "The 1995 NRC Rankings of Doctoral Programs: A Hedonic Model”, Change 28 (May/June 1996):46-54

Ronald Ehrenberg and Peter Hurst, "The 1995 Rankings of Graduate Programs: A Hedonic Model", Economics of Education Review 17 (April 1998):137-148

Ronald Ehrenberg and George Jakubson, Advance Notice Provisions in Plant Closing Legislation (Kalamazoo MI: Upjohn Institute for Employment Research, 1988)

Ronald Ehrenberg, Michael Matier, and Peter Fontanella, "Cornell University Confronts the End of Mandatory Retirement", in Robert Clark and Brett Hammond Eds. To Retire or Not to Retire: Retirement Policies and Practices in Higher Education (Philadelphia PA: University of Pennsylvania Press, 2000) 
Ronald Ehrenberg and Susan Murphy, "What Price Diversity? The Death of Need-Based Financial Aid at Selective Private Colleges", Change 25(July/August 1993): $64-73$

Ronald Ehrenberg and Ronald Oaxaca, "Unemployment Insurance, Duration of Unemployment, and Subsequent Wage Gain", American Economic Review 66 (December 1976):754-766

Ronald Ehrenberg, Paul Pieper, and Rachel Willis, "Do Economics Departments with Lower Tenure Probabilities Pay Higher Faculty Salaries", Review of Economics and Statistics, 80 (November 1998):503-512

Ronald Ehrenberg and Robert Smith, Modern Labor Economics (Glenview IL: Scott Foresman: 1982)

Ronald Ehrenberg, Harriet Zuckerman, Jeffrey Groen and Sharon Brucker, Educating Scholars; Doctoral Education in the Humanities (Princeton NJ: Princeton NJ: 2010)

Eric Eide, Dominic Brewer, and Ronald Ehrenberg, "Does it Pay to Attend an Elite Private College? Evidence on the Effects of Undergraduate College Quality on Graduate School Attendance", Economics of Education Review 17 (October 1998):371376

Michael Grossman, "On the Concept of Health Capital and the Demand for Health”, Journal of Political Economy 80 (March/April 1972):223-255 2014)

Daniel Hamermesh, "Age, Cohort and Co-Authorship" (working paper, July

Daniel Hamermesh and Neal Soss, "An Economic Theory of Suicide", Journal of Political Economy 82 (January/February 1974):83-98

James Monks and Ronald Ehrenberg, "U.S New \& World Report Rankings: Why Do They Matter?" Change 31 (November/December 1999): 42-51

Richard Stone, Linear Expenditure Systems and Demand Analysis: An Application to the Pattern of British Demand", Economic Journal 64 (September 1954):511-527 
Table 1

Numbers of Publications with Coauthors

(Share with coauthors)

\begin{tabular}{|c|c|c|c|c|c|c|c|c|c|c|}
\hline Year & Total & $\begin{array}{l}70- \\
74\end{array}$ & $75-79$ & $\begin{array}{l}80- \\
84\end{array}$ & $\begin{array}{l}85- \\
89\end{array}$ & $\begin{array}{l}90- \\
94\end{array}$ & $\begin{array}{l}95- \\
99\end{array}$ & $\begin{array}{l}00- \\
04\end{array}$ & $\begin{array}{l}05- \\
09\end{array}$ & $\begin{array}{l}10- \\
14\end{array}$ \\
\hline $\begin{array}{l}\text { Number of } \\
\text { Publications }\end{array}$ & 169 & 9 & 15 & 21 & 17 & 14 & 18 & 32 & 24 & 19 \\
\hline $\begin{array}{l}\text { No. w/ } \\
\text { Coauthors }\end{array}$ & $\begin{array}{l}102 \\
(.60)\end{array}$ & $\begin{array}{l}\mathbf{0} \\
(\mathbf{0})\end{array}$ & $\begin{array}{l}13 \\
(.87)\end{array}$ & $\begin{array}{l}16 \\
(.76)\end{array}$ & $\begin{array}{l}13 \\
(.76)\end{array}$ & $\begin{array}{l}12 \\
(.86)\end{array}$ & $\begin{array}{l}11 \\
(.61)\end{array}$ & $\begin{array}{l}14 \\
(.44)\end{array}$ & $\begin{array}{l}13 \\
(.54)\end{array}$ & $\begin{array}{l}10 \\
(.53)\end{array}$ \\
\hline $\begin{array}{l}\text { No. w/ Grad } \\
\text { Coauthors }\end{array}$ & 56 & 0 & 2 & 10 & 7 & 8 & 7 & 7 & 9 & 6 \\
\hline $\begin{array}{l}\text { No. w/ } \\
\text { Undergrad } \\
\text { Coauthors }\end{array}$ & 13 & 0 & 1 & 0 & 0 & 0 & 0 & 7 & 3 & 2 \\
\hline $\begin{array}{l}\text { No. w/ Own } \\
\text { Institution } \\
\text { Faculty } \\
\text { Coauthors }\end{array}$ & 28 & 0 & 3 & 8 & 6 & 2 & 0 & 0 & 5 & 4 \\
\hline $\begin{array}{l}\text { No. w/ Own } \\
\text { Institution } \\
\text { Other } \\
\text { Coauthors }\end{array}$ & 6 & 0 & 0 & 0 & 1 & 2 & 1 & 2 & 0 & 0 \\
\hline $\begin{array}{l}\text { No. w/ Other } \\
\text { Faculty } \\
\text { Coauthors }\end{array}$ & 16 & $\mathbf{0}$ & 5 & 1 & 1 & 1 & 4 & 2 & 0 & 2 \\
\hline $\begin{array}{l}\text { No. w/ Other } \\
\text { Coauthors }\end{array}$ & 8 & $\mathbf{0}$ & 0 & 0 & 0 & 0 & 0 & 1 & 2 & 5 \\
\hline
\end{tabular}


Table 2

Does the Pattern of Publications Change Over Time?

\begin{tabular}{|l|l|l|l|l|l|}
\hline $\begin{array}{l}\text { Number } \\
\text { Publications }\end{array}$ & Period & $\begin{array}{l}\text { Journal } \\
\text { Articles }\end{array}$ & Chapters & Magazines & Books \\
\hline 169 & $\begin{array}{l}\text { Entire } \\
\text { Sample }\end{array}$ & $\mathbf{9 1}(.54)$ & $38(.22)$ & $28(.17)$ & $12(.07)$ \\
\hline 9 & $70-74$ & $7(.78)$ & $0(0)$ & $0(0)$ & $2(.22)$ \\
\hline 15 & $75-79$ & $11(.73)$ & $2(.13)$ & $0(0)$ & $2(.13)$ \\
\hline 21 & $\mathbf{8 0 - 8 4}$ & $14(.67)$ & $4(.19)$ & $0(0)$ & $3(.14)$ \\
\hline 17 & $\mathbf{8 5 - 8 9}$ & $7(.41)$ & $8(.47)$ & $0(0)$ & $2(.12)$ \\
\hline 14 & $90-94$ & $7(.50)$ & $4(.29)$ & $2(.14)$ & $1(.07)$ \\
\hline 18 & $95-99$ & $11(.61)$ & $2(.11)$ & $5(.28)$ & $0(0)$ \\
\hline 32 & $00-04$ & $12(.38)$ & $8(.25)$ & $11(.34)$ & $1(.03)$ \\
\hline 24 & $05-09$ & $12(.50)$ & $7(.29)$ & $5(.21)$ & $0(0)$ \\
\hline 19 & $10-14$ & $10(.53)$ & $3(.16)$ & $5(.26)$ & $1(.05)$ \\
\hline
\end{tabular}




\section{Table 3}

\section{Logit Equations for the Probability of a Publication Being Coauthored}

\begin{tabular}{|l|l|l|}
\hline Ind. Var. & $\begin{array}{l}\text { Coefficient } \\
\text { (std. err. })\end{array}$ & $\begin{array}{l}\text { Coefficient } \\
\text { (std. err.) }\end{array}$ \\
\hline CHAP &.$- .470(.398)$ & $.341(.579)$ \\
\hline MAG &.$- .908(.465) * *$ & $.359(.676)$ \\
\hline BOOK & $-.080(.660)$ & $.760(.938)$ \\
\hline TIME & $-.009(.014)$ & $.026(.021)$ \\
\hline ECONO & & $\mathbf{3 . 6 9 1}(.521)^{*}$ \\
\hline THEORY & & $.379(.888)$ \\
\hline Pseudo $\mathbf{R}^{2} / \mathbf{n}$ & $.027 / 169$ & $.373 / 169$ \\
\hline
\end{tabular}

$*(* *)$ coefficient is statistically significantly different from zero at the $.05(.10)$ level of significance

where

$\mathrm{CHAP}=1$ if chapter, $=0$ otherwise

$\mathrm{MAG}=1$ if magazine article, $=0$ otherwise

$\mathrm{BOOK}=1$ if book, $=0$ otherwise

(the omitted category is journal articles)

$\mathrm{ECONO}=1$ if an econometric study, $=0$ otherwise

THEORY $=1$ if the publication develops a theoretical model, $=0$ otherwise

YEAR -time trend 
Table 4

Number of Coauthors per Coauthored Paper

\begin{tabular}{|l|l|}
\hline Period & Mean Number of Coauthors \\
\hline Entire Sample & 1.608 \\
\hline $1975-79$ & 1.308 \\
\hline $1980-84$ & 1.25 \\
\hline $1985-89$ & 1.385 \\
\hline $1990-94$ & 1.583 \\
\hline $1995-99$ & 1.455 \\
\hline $2000-04$ & 1.714 \\
\hline $2005-09$ & 2.000 \\
\hline $2010-14$ & 2.4 \\
\hline
\end{tabular}


Table 5

Edited Conference Volumes and Symposia

Ronald G. Ehrenberg ed., Do Compensation Policies Matter? (Ithaca NY: ILR Press, 1990)

Ronald G. Ehrenberg ed., Choice or Consequences: Contemporary Policy Issues in Education (Ithaca NY: ILR Press, 1994)

Ronald G. Ehrenberg ed., The American University: National Treasure or Endangered Species (Ithaca NY: Cornell University Press, 1997)

Francine D Blau and Ronald G. Ehrenberg eds., Gender and Family Issues in the Workplace (New York NY: Russell Sage 1997)

F. King Alexander and Ronald G. Ehrenberg eds. Maximizing Resources: Universities, Public Policy and Revenue Production eds. (San Francisco CA: Jossey Bass, 2003)

Press, 2005)

Ronald G. Ehrenberg ed., Governing Academia (Ithaca NY: Cornell University

Ronald G. Ehrenberg ed. What's Happening to Public Higher Education? (Baltimore MD: Johns Hopkins University Press, 2007)

Paula E. Stephan and Ronald G. Ehrenberg eds., Science and the University (Madison WI: University of Wisconsin Press, 2007)

Madeleine B. d'Ambrosio and Ronald G. Ehrenberg, Transformational Change in Higher Education: Positioning Colleges and Universities for Success (New York NY: TIAA-CREF Series on Higher Education, 2008)

Ronald G. Ehrenberg and Charlotte V. Kuh eds., Doctoral Education and the Faculty of the Future (New York NY: Cornell University Press, 2009)

Ronald G. Ehrenberg ed., "Symposium: Persistence Rates in STEM Field Majors", Economics of Education Review 29 (December 2010):888-946 


\section{Appendix A}

\section{Coauthors}

\begin{tabular}{|c|c|c|c|}
\hline Name & Type & Name & Type \\
\hline Deborah Anderson & $\mathrm{G}$ & Jared Levin & U \\
\hline Orley Ashenfelter & OF & Jean Li & G \\
\hline Corry Azzi & $\mathrm{F}$ & Albert Liu & G \\
\hline Jean Baderschneider & G & Rebecca Luzadis & G \\
\hline Burt Barnow & OF & Joyce Main & G \\
\hline M ichael Bognanno & $\mathrm{G}$ & Alan M arcus & G \\
\hline Dominic Brewer & G & M irinda M artin & G \\
\hline Sharon Brucker & OF & Michael Matier & 10 \\
\hline Richard Butler & $\mathrm{F}$ & Pangiatos M avros & G \\
\hline Richard Chaykowski & G & Marquise M cCraw & $\mathrm{U}$ \\
\hline John Cheslock & $\mathrm{G}$ & George Milkovich & $\mathrm{F}$ \\
\hline Charles Clotfelter & OF & Mordechai Mironi & G \\
\hline Scott Condie & G & James M onks & OF \\
\hline Leif Danzinger & $\mathrm{F}$ & Jesenka M rdjenovic & $\bar{U}$ \\
\hline Claude Desjardins & OF & Susan M urphy & 10 \\
\hline Eric Ehrenberg & $E$ & Mathew Nagowski & U \\
\hline Randy Ehrenberg & $E$ & Ronald Oaxaca & $\mathrm{F}$ \\
\hline Eric Eide & OF & Robert Olsen & G \\
\hline Thomas Eisenberg & $\mathrm{U}$ & Richard Patterson & G \\
\hline Julia Epfantseva & G & Paul Pieper & $\mathrm{OF}$ \\
\hline Robert Flanagan & OF & Joseph Price & G \\
\hline Peter Fontanella & 10 & Pamela Rosenberg & 10 \\
\hline Malcom Getz & OF & Daniel Rees & G \\
\hline Steven Goldberg & $U$ & M ichael Rizzo & G \\
\hline Gerald Goldstein & OF & Donna Rothstein & G \\
\hline Dan Goldhaber & $\mathrm{G}$ & Gee San & G \\
\hline Jeff Groen & $\mathrm{F}$ & Paul Schumann & G \\
\hline Kevin Hallock & $\mathrm{F}$ & Ronald Seeber & $\mathrm{F}$ \\
\hline James Hewlet & G & Dan Sherman & G \\
\hline Peter Hurst & 10 & John Siegfried & OF \\
\hline George Jakubson & $\mathrm{F}$ & Chris Smith & U \\
\hline Todd Jick & G & Robert Smith & $\mathrm{F}$ \\
\hline Lawrence Kahn & $\mathrm{F}$ & Eric So & G \\
\hline Herschel Kasper & $\mathrm{F}$ & Doug Webber & G \\
\hline Andrew Key & $U$ & Kenneth Whelan & G \\
\hline Adam Kezbom & $U$ & Rachel Willis & $\mathrm{OF}$ \\
\hline Dan Klaff & $\mathrm{U}$ & J. Douglas Willms & OF \\
\hline Thomas Kochan & $\mathrm{F}$ & Liang Zhang & G \\
\hline Dimitry Kotlaerenko & $U$ & Harriet Zuckerman & $\mathrm{OF}$ \\
\hline
\end{tabular}

Where

F Faculty, visiting faculty and postdocs at my own institution

G Graduate students

U Undergraduate students

E Ehrenberg family (wife and son)

OF Faculty and staff at other universities and organizations

IO Administrators and staff at my own institution 